\title{
KINERJA TENAGA LABORAN DAN TEKNISI LABORATORIUM REKAYASA DI FAKULTAS TEKNIK UNIVERSITAS NEGERI SEMARANG DAN FAKTOR- FAKTOR DOMINAN YANG MEMPENGARUHINYA
}

\author{
Said Sunardiyo \\ Jurusan Teknik Elektro \\ Fakultas TeknikUniversitas Negeri Semarang \\ Gedung E8 Lt.2 Kampus Unnes Sekarang Gunungpati Semarang \\ Email : saidelektro@gmail.com
}

\begin{abstract}
Abstrak. Keberadaan laboran dan teknisi di suatu laboratorium sangatlah penting dalam menentukan keberhasilan akademik dosen dan mahasiswa. Tujuan penelitian ini adalah memotret kinerja tenaga laboran dan teknisi serta ingin mengungkap faktor penunjang dan kendala kinerjanya. Manfaat penelitian ialah bagi pengelola Fakultas dan Jurusan sebagai masukan informasi dalam mengambil kebijakan dalam peningkatan kerja SDM laboran dan teknisi laboratorium. Penelitian ini dilakukan di FT Unnes, variabel yang diamati ialah kinerja laboran dan teknisi dalam menjalankan tugas di laboratorium rekayasa di FT Unnes Berdasarkan hasil penelitian maka disimpulkan bahwa (1) Laboran dan teknisi laboratorium rekayasa Fakultas Teknik Unnes memiliki kinerja yang baik pada pelaksanaan dimensi kompetensi kepribadian, sosial, administratif dan profesional (2) Kinerja tenaga laboran dan teknisi laboratorium dipengaruhi oleh adanya faktor penunjang yaitu faktor internal (pribadi) : kemampuan profesi latar belakang pendidikan dan pengalaman. Untuk faktor eksternal (lingkungan) : pemimpin yang baik (kepala laboratorium) dalam hal ini koordinasi tugas bagi tenaga laboran/teknisi. Sedangkan faktor penghambat yaitu kurangnya pelatihan-pelatihan profesi bagi tenaga laboran. Saran yang direkomendasikan ialah : (1) Guna peningkatan kinerja laboran dan teknisi laboratorium rekayasa Fakultas Teknik Unnes perlu adanya koordinasi pengelolaan manajemen laboratorium berbasis ISO oleh pimpinan Fakultas bersama Jurusan/Prodi.(2) Perlu adanya penyegaran keilmuan dan ketrampilan bagi laboran dan teknisi melalui pelatihan-pelatihan teknis laboratorium baik internal maupun di luar kampus.
\end{abstract}

Kata kunci : kinerja laboran dan teknisi, laboratorium rekayasa

\begin{abstract}
The existence of a laboratory assistant in the laboratory is very important in determining the academic success of faculty and students. The purpose of this study is to photograph the performance of laboratory staff and technicians and want to uncover the factors that support and performance constraints. The benefits of this study was to Faculty and Department managers as input information in making policy in an increase in HR laboratory work and laboratory technicians. This research was conducted in the FT Unnes, observed variables are performance laboratory staff and technicians in performing their duties in the engineering lab at the FT Unnes Based on the results, we conclude that (1) laboratory assistant and lab technician engineering, Faculty of Engineering Unnes have good performance in the implementation of the dimensions of personal competence, social, administrative and professional (2) performance of laboratory personnel and laboratory technicians is influenced by the presence of the supporting factors of internal factors (personal): the ability of professional educational background and experience. To external factors (environment): a good leader (head of laboratory) in this case coordination tasks for laboratory staff / technicians. While the limiting factor is the lack of professional training for laboratory personnel. Suggestions are recommended: (1) In order to increase the performance of laboratory staff and laboratory technicians engineering, Faculty of Engineering Unnes need to coordinate the management of the ISO-based laboratory management by the leadership of the Faculty with the Department / Study Program. (2) There needs to refresh the knowledge and skills for laboratory staff and technicians through training laboratory technical training both internally and outside the campus.
\end{abstract}

Keywords: performance, laboratory staff and technicians, laboratory 


\section{PENDAHULUAN}

Universitas Negeri Semarang (UNNES) memiliki visi menjadi universitas konservasi, bertaraf internasional, yang sehat, unggul, dan sejahtera. Terkait dengan visi, misi dan tujuan UNNES, maka penerapan nilai-nilai konservasi ke seluruh komponen di perguruan pendidikan tinggi ini perlu segera direalisakan. Melalui implementasi di masing-masing Unit Teknis, Fakultas, Jurusan, Prodi, Gugus, dan seterusnya. Di sisi lain hal ini untuk meningkatkan mutu tata kelola dan pencitraan publik serta peningkatan manajemen kelembagaan, fakultas, jurusan, program studi dan unit-unit yang ada di Unnes Konservasi. Termasuk di dalamnya adalah fungsi laboran dan teknisi yang cukup strategis dalam pembelajaran berbasis praktikum di laboratorium.

Laboran adalah Tenaga Kependidikan yang bekerja di laboratorium dan membantu proses pembelajaran mahasiswa vokasi dan akademik Strata 0, 1, 2 dan 3, serta penelitian dosen. Keberadaan Laboran di suatu laboratorium sangatlah penting dalam menentukan keberhasilan akademik dosen dan mahasiswa. Untuk itu, Laboran seyogyanya memiliki hard skills dan soft skills yang memadai. Inisiatif, ketekunan, kreatifitas, kecakapan dan keterampilan serta pengetahuan yang dikuasai oleh Laboran, membantu efisiensi dan efektifitas serta produktivitas dari laboratorium yang dikelola oleh perguruan tinggi (Pedoman Umum Pemilihan Laboran Berprestasi, No.03/PP/ DITDIKTENDIK/2011).

Fakultas Teknik Universitas Negeri Semarang saat memiliki 4 jurusan Teknik Elektro, Teknik Sipil, Teknik Mesin dan Teknologi Jasa dan Produksi dengan 13 Program Studi, yang semuanya didukung keberadaan laboratorium. Ketersediaan tenaga laboran dan teknisi sangat menentukan keberhasilan pembelajaran yang selanjutnya akan menunjang terhadap keberhasilan dalam akreditasi BAN-PT untuk program studi. Sehingga dilihat dari perannya dalam pembelajaran sangatlah penting, karena salah satu pilar utama pendidikan vokasi/keteknikan sangat bergantung pada eksistansi laboratorium.

Di lapangan Tenaga Laboran dan Teknisi saat ini direkrut oleh Universitas melalui usulan Jurusan dengan melalui ujian yang bermateri umum maupun keteknikan. Hasil paparan rapat kerja FT 2012 menjelaskan bahwa hanya sebagian saja tenaga laboran dan teknisi yang memenuhi kompetensi sesuai 
bidangnya. Hal ini jelas menyiratkan bahwa ada laboran yang belum memiliki kapasitas yang diharapkan. Sampai saat ini tenaga laboran belum bekerja secara maksimal dan belum pernah diukur bagaimana kinerja mereka dalam melaksanakan tugas-tugas sesuai job deskripsi atau tupoksi, sejauhmana sebenarnya kinerja tenaga laboran dan teknisi di laboratorium rekayasa Fakultas Teknk Unnes. Sehingga penting dilakukan kajian sejauhmana kinerja tenaga laboran dan teknisi serta faktor penunjang dan penghambat yang mempengaruhi kinerja tenaga laboran dan teknisi.

Berdasarkan permasalahan yang dipaparkan di latar belakang, maka rumusan masalah pada penelitian ini adalah sejauhmana kinerja tenaga laboran dan teknisi laboratorium rekayasa Fakultas Teknik dalam menunjang keberhasilan pembelajaran, juga faktor-faktor penunjang dan kendala apa saja yang mempengaruhi kinerja tenaga laboran dan teknisi

\section{METODE}

Penelitian ini dilaksanakan di Laboratorium rekayasa Jurusan Teknik Sipil, Teknik Mesin, Teknik Elektro, Teknik Kimia dan Teknologi Jasa dan Produksi Fakultas Teknik Universitas Negeri Semarang. Jangka waktu penelitian ini adalah 6 bulan. Variabel yang diamati kinerja tenaga laboran dan teknisi laboratorium rekayasa di 4 Jurusan dan 1 Prodi di Fakultas Teknik Unnes. Teknik pengumpulan data dilakukan melalui observasi wawancara dengan pengelola laboratorium. Instrumen penelitian berupa lembar observasi dan pedoman wawancara.

Teknik analisis yang dipergunakan ialah analisis deskriptif, hasilnya untuk menggambarkan tingkat kinerja tenaga laboran dan teknisi dan faktor-faktor yang pendukung dan penghambatnya di laboratorium rekayasa Fakultas Teknik UNNES.

\section{HASIL DAN PEMBAHASAN}

\section{(1) Kinerja Laboran dan Teknisi}

Data jumlah Laboran dan Teknisi di 4 Jurusan Fakultas Teknik adalah 35 orang. Terdistribusi di Jurusan Teknik Sipil 7 orang, Teknik Elektro 9 orang, 
Teknik Mesin 9 orang, Teknik Kimia 2 orang, dan TJP 9 orang. Berdasarkan hasil observasi maka diperoleh hasil seperti pada tabel 1 dan tabel 2:

Tabel 1. Data Kinerja Berdasarkan Aspek Kompetensi Kepribadian, Sosial, Administratif dan Profesional

\begin{tabular}{|c|c|c|c|c|c|c|}
\hline \multirow[t]{2}{*}{$\begin{array}{l}\text { DIMENSI } \\
\text { KOMPETENSI }\end{array}$} & \multirow[t]{2}{*}{ KOMPETENSI } & \multicolumn{5}{|c|}{$\begin{array}{l}\text { Rerata Kinerja } \\
\text { Laboran/Teknisi } \\
\text { Jurusan }(\%)\end{array}$} \\
\hline & & Mesin & Sipil & Elektro & TJP & Kimia \\
\hline \multirow[t]{2}{*}{$\begin{array}{l}\text { Kompetensi } \\
\text { Kepribadian }\end{array}$} & $\begin{array}{l}\text { Menampil kan diri sbg pribadi } \\
\text { yg dewasa, mantap dan } \\
\text { berakhlak mulia }\end{array}$ & 100 & 100 & 100 & 100 & 100 \\
\hline & Menunjuk kan komitmen tugas & 88,9 & 85,7 & 88,9 & 88,9 & 50 \\
\hline \multirow[t]{2}{*}{$\begin{array}{l}\text { Kompetensi } \\
\text { Sosial }\end{array}$} & $\begin{array}{l}\text { Bekerja sama dlm pelaksanaan } \\
\text { tugas }\end{array}$ & 88,9 & 85,7 & 88,9 & 88,9 & 100 \\
\hline & $\begin{array}{l}\text { Berkomunikasi secara lisan dan } \\
\text { tulisan }\end{array}$ & 100 & 100 & 100 & 100 & 100 \\
\hline $\begin{array}{l}\text { Kompetensi } \\
\text { Administratif }\end{array}$ & $\begin{array}{l}\text { Menginven tarisasi bahan } \\
\text { praktikum }\end{array}$ & 100 & 100 & 100 & 100 & 100 \\
\hline
\end{tabular}

\begin{tabular}{llccccc} 
& Mencatat kegiatan praktikum & 100 & 100 & 100 & 100 & 100 \\
\hline $\begin{array}{l}\text { Kompetensi } \\
\text { Profesional }\end{array}$ & Merawat Ruang Laboratorium & 100 & 100 & 100 & 100 & 100 \\
& $\begin{array}{l}\text { Mengelola bahan dan peralatan } \\
\text { laboratorium }\end{array}$ & 100 & 100 & 100 & 100 & 100 \\
& $\begin{array}{l}\text { Melayani kegiatan praktikum } \\
\text { Menjaga kesehatan dan }\end{array}$ & 100 & 100 & 100 & 100 & 100 \\
& $\begin{array}{l}\text { keselamatan kerja di } \\
\text { laboratorium }\end{array}$ & & & & & \\
&
\end{tabular}

Tabel 2. Faktor Penunjang dan Penghambat

\begin{tabular}{|c|c|c|}
\hline \multirow{2}{*}{$\begin{array}{l}\text { DIMENSI } \\
\text { KOMPETENSI }\end{array}$} & \multirow[t]{2}{*}{ KOMPETENSI } & $\begin{array}{l}\text { Penunjang dan Penghambat Kinerja } \\
\text { Laboran/Teknisi }\end{array}$ \\
\hline & & Elektro \\
\hline \multirow{4}{*}{$\begin{array}{l}\text { Kompetensi } \\
\text { Kepribadian }\end{array}$} & Menampil kan diri & Rata-rata laboran/teknisi menunjukkan \\
\hline & $\begin{array}{l}\text { sbg pribadi yg } \\
\text { dewasa, mantap }\end{array}$ & $\begin{array}{l}\text { karakter jujur, disiplin, dsn tanggung } \\
\text { jawab. }\end{array}$ \\
\hline & dan berakhlak & laboran/teknisi \\
\hline & mulia & $\begin{array}{l}\text { menjalankan ibadah menurut agama dan } \\
\text { keyakinan masing-masing. }\end{array}$ \\
\hline
\end{tabular}


(3) Suasana religius di Fakultas Teknik Unnes seperti sholat berjamaah di masjid Salman Al Farizi, juga adanya mushola kantor di jurusan-jurusan mendukung terbangunnya sikap dan kepribadian yang mulia.

(4) Adanya pembinaan mental melalui kegiatan keagamaan.

Menunjuk kan

komitmen tugas

\section{Kompetensi}

Sosial
Bekerja sama dlm pelaksanaan tugas
(1) Adanya Perbedaan Tenaga PNS, Kontrak dan Honorer dalam melakukan kegiatan bersama (upah/honor, beban kerja).

(2) Sebagian besar Laboran/teknisi yang berstatus kontrak dan honorer memiliki semangat kerja yang lebih baik dari yang berstatus PNS, dengan harapan dengan menampilkan kinerja yang baik mereka bisa segera diangkat sebagai PNS. 
Berkomuni kasi secara lisan dan tulisan
(1) Sebagian besar laboran/teknisi mampu memanfaatkan peralatan TIK untuk berkomunikasi.

(2) Di setiap laboratorium dilengkapi dangan PC.

(3) Semua laboran/teknisi di FT sering dilibatkan dalam kepanitiaan di Fakultas sehingga mendukung kemampuan mereka dalam berkomunikasi baik lisan maupun tulisan.

(4) Tingkat pendidikan, pengalaman dan masa kerja laboran dan teknisi mempengaruhi kemampuan berkomunikasi baik lisan maupun tulisan.

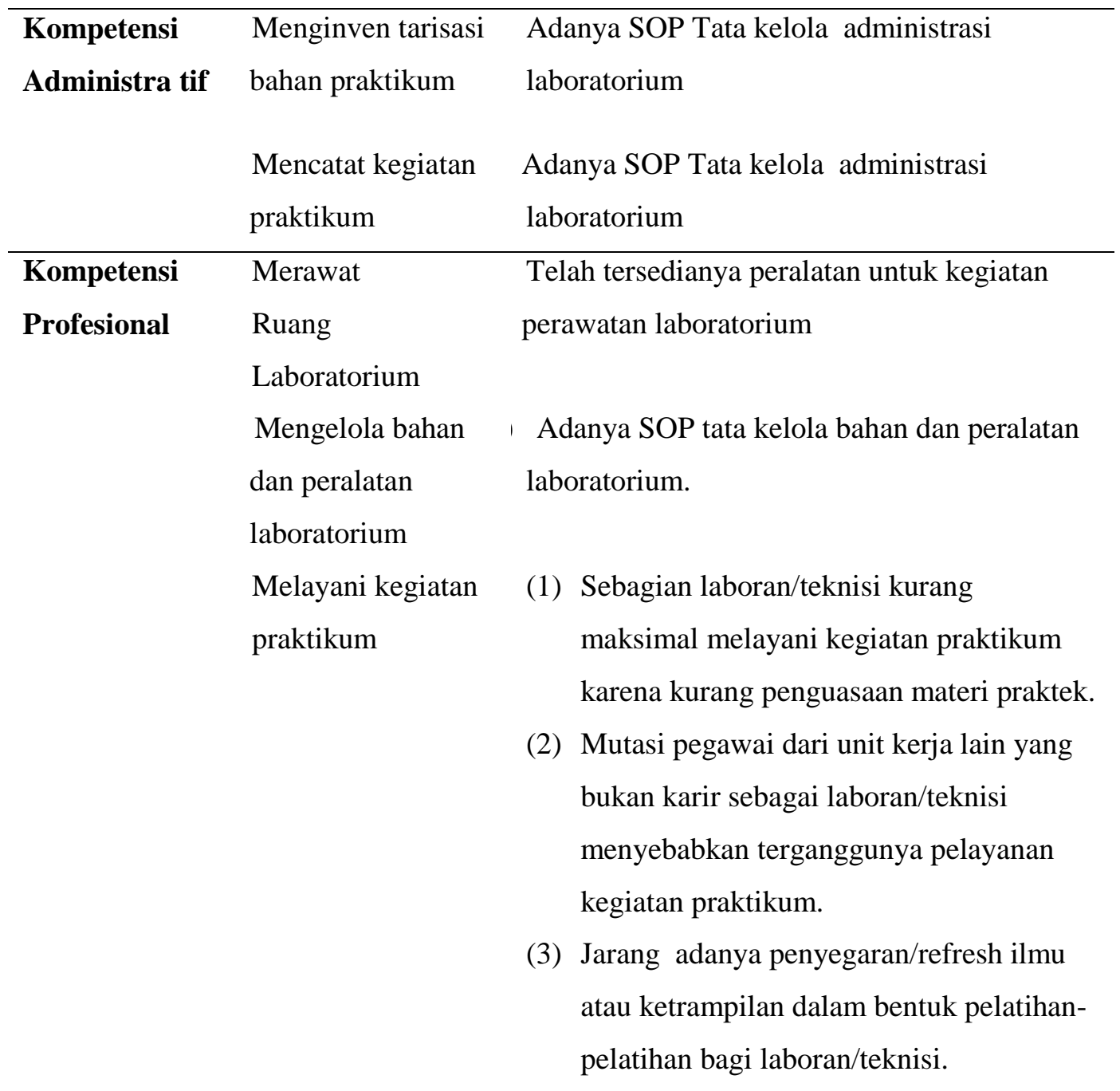




\begin{tabular}{|c|c|}
\hline Menjaga kesehatan & (1) Perangkat pertolongan dan keselamatan \\
\hline dan keselamatan & kerja di laboratorium sebagian besar \\
\hline kerja di & sudah ada. \\
\hline laboratorium & (2) Laboran/teknisi telah memiliki \\
\hline
\end{tabular}

Berdasarkan hasil penelitian menunjukkan bahwa kinerja laboran/teknisi yang bekerja di laboratorium rekayasa Fakultas Teknik Unnes pada dimensi kompetensi kepribadian khususnya kompetensi : "Menampilkan diri sebagai pribadi yang dewasa, mantap dan berakhlak mulia" rata-rata sangat baik (100\%) hal ini menunjukkan bahwa karakter pribadi seperti berperilaku jujur, arif, mandiri, dan ketaatan menjalankan agama dan norma hukum telah melekat dan ditampilkan dalam bekerja sebagai laboran/teknisi.

Terkait dengan kompetensi "menunjukkan komitmen terhadap tugas" bahwa belum seluruhnya laboran/teknisi meskipun adanya keteladanan dari pimpinan Fakultas dan Jurusan/Prodi mengenai perilaku disiplin, beretos kerja tinggi, bertanggungjawab, tekun, teliti, hati-hati dalam tugas, kreatif dan berorientasi terhadap kualitas. Sebagian laboran/teknisi belum seluruhnya menjalankan tugas dengan sepenuh hati sesuai tupoksinya, ada yang menunggu perintah atau melaksankan dengan sungguh-sungguh apabila ada supervisi. Tingkat pendidikan, pengalaman dan masa kerja laboran/teknisi mempengaruhi performa dalam menjalankan tugas.

Kinerja pada aspek Kompetensi Sosial yaitu untuk kompetensi "bekerjasama dalam pelaksanaan tugas" rata-rata ( <100\%) laboran/teknisi belum seluruhnya mantap dalam melakukan kerjasama dalam tugas. Hambatan yang dijumpai di lapangan yaitu variasi status laboran/teknisi dalam hal ini terkait adanya besarnya upah, gaji serta beban kerja antara PNS, kontrak dan honorer. Sebagian besar laboran/teknisi yang berstatus kontrak dan honorer memiliki semangat kerja yang lebih baik dari yang berstatus PNS, dengan harapan dengan menampilkan kinerja yang baik mereka bisa segera diangkat 
sebagai PNS. Sedangkan dalam kompetensi "berkomunikasi secara lisan dan tulisan" sebagian besar laboran/teknisi mampu memanfaatkan perangkat komputer sebagai sarana administrasi dan berkomunikasi, hal lain yang mendukung kemampuan berkomunikasi secara lisan maupun tulisan ialah keterlibatan mereka dalam tugas-tugas kepanitiaan baik Fakultas maupun Jurusan/Prodi. Tingkat pendidikan, pengalaman dan masa kerja laboran/teknisi mempengaruhi kemampuan berkomunikasi.

Kinerja laboran/teknisi pada Dimensi Kompetensi Administratif yaitu untuk kompetensi : mengiventarisasi bahan praktikum dan mencatat kegiatan praktikum menunjukkan seluruhnya $100 \%$. Hal ini ini menunjukkan bahwa pada dua kompetensi tersebut laboran/teknisi menunjukkan npresatsi kerja yang maksimal. Hal ini ditunjang oleh tata kelola administrasi laboratorium telah dilaksanakan dengan runtut dan baik.

Kinerja laboran/teknisi ditinjau dari pelaksanaan dimensi kompetensi Profesional secara menyeluruh menunjukkan hasil yang memuaskan untuk kompetensi "merawat ruang laboratorium" hal ini dikarenakan telah tersedianya peralatan untuk kegiatan perawatanruang laboratorium. Kinerja yang tinggi juga ditunjukkan pada kompetensi "mengelola bahan dan peralatan laboratorium", dukungan adanya SOP pengelolaan bahan dan alat laboratorium telah dilaksanakan dengan baik. Pada pelaksanaan "pelayanan kegiatan praktikum" kinerja laboran/teknisi masih belum maksimal, hal ini terkendala oleh (1) sebagian laboran/teknisi kurang maksimal melayani kegiatan praktikum karena kurang penguasaan materi praktek. (2) Mutasi pegawai dari unit kerja lain yang bukan karir sebagai laboran/teknisi menyebabkan terganggunya pelayanan kegiatan praktikum. (3) Jarang adanya penyegaran/refresh ilmu dan ketrampilan dalam bentuk pelatihan-pelatihan bagi laboran/teknisi. Sedangkan yang berkaitan dengan kompetensi "menjaga keselamatan dan kesehatan kerja" karena laboran/teknisi telah memiliki pengetahuan yang cukup tentang Keselamatan dan Kesehatan Kerja di Laboratorium maka secara keseluruhan memiliki kinerja yang baik.

Ditinjau faktor-faktor yang menunjang kinerja tenaga laboran/teknisi laboratorium bahwa peran kepala laboratorium sebagai atasan langsung sangat 
berpengaruh. Koordinasi yang baik dalam pelaksanaan tugas-tugas di laboratorium dominan menunjang kinerja yang ditunjukkan tenaga laboran/teknisi. Di sisi lain kemampuan pribadi masing-masing berupa latar belakang pendidikan dan pengalaman berkontribusi positip. Juga tata kelola berupa SOP pelaksanaan tugas seperti inventarisasi alat dan bahan, serta. pelayanan kepada dosen dan mahasiswa.

Sedangkan faktor penghambat yaitu ada sebagian tenaga laboran/teknisi yang jarang mengikuti pelatihan-pelatihan profesi, seperti kursus singkat, pada umumnya mengalami hambatan dengan tugas-tugas mereka. Meskipun dalam waktu yang panjang akhirnya dapat menyesuaikan diri.

\section{KESIMPULAN}

Berdasarkan hasil penelitian maka dapat disimpulkan bahwa : (1) Laboran dan teknisi laboratorium rekayasa Fakultas Teknik Unnes memiliki kinerja yang baik pada pelaksanaan dimensi kompetensi kepribadian, sosial, administratif dan profesional. (2) Kinerja tenaga laboran dan teknisi laboratorium dipengaruhi oleh adanya faktor penunjang yaitu faktor internal (pribadi) : kemampuan profesi latar belakang pendidikan dan pengalaman. Untuk faktor eksternal (lingkungan) : pemimpin yang baik (kepala laboratorium) dalam hal ini berkoordinasi terkait tugas tenaga laboran/teknisi. Sedangkan faktor penghambat yaitu kurangnya pelatihan-pelatihan profesi bagi tenaga laboran.

Saran yang direkomendasikan ialah : (1) untuk meningkatkan kinerja laboran dan teknisi laboratorium rekayasa Fakultas Teknik Unnes perlu adanya koordinasi pengelolaan manajemen laboratorium berbasis ISO oleh pimpinan Fakultas dengan Jurusan/Prodi. (2) Perlu adanya penyegaran keilmuan dan ketrampilan bagi laboran dan teknisi melalui pelatihan-pelatihan teknis baik internal maupun eksternal kampus. 


\section{DAFTAR PUSTAKA}

Alim Sumarno, 2011. Fungsi Laboratorium. dalam :

http://elearning.unesa.ac.id/myblog/alim-sumarno/fungsi-laboratorium

Badan Akreditasi Nasional PT. Akreditasi Insitusi Perguruan Tinggi.Buku VI. Matriks Penilaian Portofolio Akreditasi Institusi. Depdiknas 2007.

Ditdiktendik. 2011. Pedoman Umum Pemilihan Laboran Berprestasi. Direktorat Jenderal Pendidkan Tinggi, Direktorat Pendidik dan Tenaga Kependidikan Kemendiknas RI.

Permendiknas. No. 26 Tahun 2008, tentang : Standar Tenaga Laboratorium Sekolah /Madrasah. Mendiknas RI 2008.

Visi, Misi dan Tujuan Universitas Negeri Semarang. http://www.unnes.ac.id . diunduh pada 1 Pebruari 2012. 